ARTICLE

https://doi.org/10.1038/s41467-019-12274-7

\title{
Dual-phase nanostructuring of layered metal oxides for high-performance aqueous rechargeable potassium ion microbatteries
}

\author{
Ying-Qi Li (i) ${ }^{1,2}$, Hang Shi (i) ${ }^{1,2}$, Sheng-Bo Wang ${ }^{1,2}$, Yi-Tong Zhou (i) ${ }^{1}$, Zi Wen (i) ${ }^{1}$, Xing-You Lang (i) ${ }^{1}$ \& \\ Qing Jiang (iD ${ }^{1}$
}

Aqueous rechargeable microbatteries are promising on-chip micropower sources for a wide variety of miniaturized electronics. However, their development is plagued by state-of-the-art electrode materials due to low capacity and poor rate capability. Here we show that layered potassium vanadium oxides, $\mathrm{K}_{x} \mathrm{~V}_{2} \mathrm{O}_{5} \cdot \mathrm{nH}_{2} \mathrm{O}$, have an amorphous/crystalline dual-phase nanostructure to show genuine potential as high-performance anode materials of aqueous rechargeable potassium-ion microbatteries. The dual-phase nanostructured $\mathrm{K}_{x} \mathrm{~V}_{2} \mathrm{O}_{5} \cdot n \mathrm{H}_{2} \mathrm{O}$ keeps large interlayer spacing while removing secondary-bound interlayer water to create sufficient channels and accommodation sites for hydrated potassium cations. This unique nanostructure facilitates accessibility/transport of guest hydrated potassium cations to significantly improve practical capacity and rate performance of the constituent $\mathrm{K}_{x} \mathrm{~V}_{2} \mathrm{O}_{5} \cdot n \mathrm{H}_{2} \mathrm{O}$. The potassium-ion microbatteries with $\mathrm{K}_{x} \mathrm{~V}_{2} \mathrm{O}_{5} \cdot n \mathrm{H}_{2} \mathrm{O}$ anode and $\mathrm{K}_{x} \mathrm{MnO}_{2} \cdot n \mathrm{H}_{2} \mathrm{O}$ cathode constructed on interdigital-patterned nanoporous metal current microcollectors exhibit

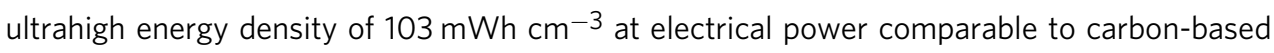
microsupercapacitors.

\footnotetext{
${ }^{1}$ Key Laboratory of Automobile Materials (Jilin University), Ministry of Education, and School of Materials Science and Engineering, Jilin University, 130022 Changchun, China. ${ }^{2}$ These authors contributed equally: Ying-Qi Li, Hang Shi, Sheng-Bo Wang. Correspondence and requests for materials should be addressed to X.-Y.L. (email: xylang@jlu.edu.cn) or to Q.J. (email: jiangq@jlu.edu.cn)
} 
C ontinuous miniaturization of self-powered flexible and portable electronics, implantable medical devices, and microelectromechanical systems (MEMS) has raised urgent demands for sufficiently compact and/or flexible energy storage to realize safe and reliable energy autonomy ${ }^{1,2}$. Many types of miniaturized energy-storage devices are being developed to power microelectronic devices as stand-alone micropower sources or intermediate energy-storage units complementing energy conversion devices (e.g., solar cells, piezoelectric nanogenerators, or thermalelectric cells $)^{1,2}$. These include traditional lithium-ion microbatteries based on volumetric reactions ${ }^{3-7}$ and microsupercapacitors based on surface adsorption/desorption or/ and redox reactions ${ }^{8-17}$. Although lithium-ion microbatteries have high gravimetric/volumetric energy ${ }^{3-7}$, the safety issues associated with highly toxic and flammable organic electrolytes besides the inferior rate capability and stability essentially impede their practical use in microelectronic devices. Whereas microsupercapacitors can tackle these problems by making use of (pseudo)capacitive energy storage in low-cost and safe waterbased electrolytes, few of them have energy density approaching that of microbatteries ${ }^{8-17}$. Therefore, it is highly desirable to explore alternative electrochemical energy-storage technologies that can store/deliver energy with lithium-ion microbattery-like capacity and microsupercapacitor-like rate performance for satisfying the versatile requirements in micro/nano-systems.

Battery chemistries based on electrochemical intercalation of alkaline or alkali-earth cations $\left(\mathrm{M}=\mathrm{Li}^{+}\right.$(ref. $\left.{ }^{18-20}\right), \mathrm{Na}^{+}$(ref. $\left.{ }^{21-24}\right)$, $\mathrm{K}^{+}$(ref. ${ }^{25-28}$ ), $\mathrm{Mg}^{2+}$ (ref. ${ }^{29}$ ), and $\mathrm{Zn}^{2+}$ (refs. ${ }^{30,31}$ )) in aqueous electrolytes are currently the most encouraging tentative, wherein the hydrated metal cations, instead of their crystalline ions, serve as charge carriers to take part in the electrochemical processes because of strong ion-solvent interactions ${ }^{32}$. By virtue of the $\mathrm{K}^{+}$cations having the smallest hydrated radii and the highest conductivity in water-based electrolytes ${ }^{33,34}$, aqueous rechargeable potassium ion microbatteries (AR-PIMBs) hold a great promise as highly safe energy-storage microdevices to store/deliver high-density energy at fast charge/discharge rates. However, few electrode materials such as transition-metal oxides (TMOs) with a layered structure (e.g., polymorphic vanadium oxides ${ }^{25}$ ) and Prussian Blue analogs (PBAs) $^{26,27}$ (nickel hexacyanoferrate ${ }^{35}$, iron hexacyanoferrate dihydrate $^{49}$, and nickel ferrocyanide ${ }^{36}$ ) have been explored for reversible hydrated $\mathrm{K}^{+}$cation intercalation. Compared with these PBAs with limited capacities $\left(\sim 60 \mathrm{mAh}^{-1}\right)$, layered vanadium pentoxides without/with pre-intercalation of alkaline or alkali-earth ions, typically amorphous $\mathrm{V}_{2} \mathrm{O}_{5}$ xerogel $\left(\mathrm{V}_{2} \mathrm{O}_{5} \cdot n \mathrm{H}_{2} \mathrm{O}\right)^{37,38}$ and $\mathrm{M}_{x} \mathrm{~V}_{2} \mathrm{O}_{5} \cdot n \mathrm{H}_{2} \mathrm{O}^{25,39}$, have large interlayer distances, which are expected to facilitate diffusion and storage of guest hydrated cations with a high theoretical capacity of $443 \mathrm{mAh} \mathrm{g}^{-1}$. Nevertheless, the state-of-the-art layered vanadium pentoxide-based electrode materials often exhibit practical capacities far below the theoretical value and deliver much lower levels of electrical power than capacitor materials ${ }^{40,41}$. This is due to the basic structure units comprised of bilayer $\mathrm{V}_{2} \mathrm{O}_{5}$ sheets and a large number of crystalline water molecules sandwiched between them ${ }^{34}$, wherein the former suffers from a low electrical conductivity and the latter blocks the intercalation of hydrated cations ${ }^{42,43}$. When removing the crystalline water to alleviate the blocking influence on the intercalation of hydrate cations, crystallization usually takes place to produce the orthorhombic $\mathrm{V}_{2} \mathrm{O}_{5}\left(o-\mathrm{V}_{2} \mathrm{O}_{5}\right)$ or the monoclinic $\mathrm{M}_{x} \mathrm{~V}_{2} \mathrm{O}_{5}$ with small interlayer spacing $38,40,44,45$, which not only fails to improve the specific capacity and rate capability but leads to extra massive volume change during the insertion/extraction of hydrated cations to limit microbattery lifetime ${ }^{38-41,43}$. Such structure tradeoff always leads to their low capacity, poor rate capability, and short lifetime, restricting the wide use of vanadium oxide-based electrode materials in AR-PIMBs.
Here we show layered potassium vanadium oxides composed of amorphous/crystalline $\mathrm{K}_{0.25} \mathrm{~V}_{2} \mathrm{O}_{5} \cdot n \mathrm{H}_{2} \mathrm{O} / o-\mathrm{V}_{2} \mathrm{O}_{5}$ dual phases $\left(a c-\mathrm{K}_{x} \mathrm{~V}_{2} \mathrm{O}_{5}\right)$ as promising anode materials of high-performance AR-PIMBs when integrated on three-dimensional (3D) bicontinuous nanoporous $\mathrm{Au}$ current microcollectors (NP Au/ac$\mathrm{K}_{x} \mathrm{~V}_{2} \mathrm{O}_{5}$ ). Therein, the amorphous $\mathrm{K}_{0.25} \mathrm{~V}_{2} \mathrm{O}_{5} \cdot n \mathrm{H}_{2} \mathrm{O}$ serves as molecular pillars to keep the large interlayer spacing while the crystalline $o-\mathrm{V}_{2} \mathrm{O}_{5}$ offers sufficient room to accommodate more guest hydrated $\mathrm{K}^{+}$cations. As a consequence, the NP Au/ac$\mathrm{K}_{x} \mathrm{~V}_{2} \mathrm{O}_{5}$ electrodes exhibit a volumetric capacity of as high as $\sim 715 \mathrm{mAh} \mathrm{cm}^{-3}$ with an exceptional rate performance. This enlists the AR-PIMBs with the $a c-\mathrm{K}_{x} \mathrm{~V}_{2} \mathrm{O}_{5}$ anode and the cryptomelane $\mathrm{K}_{x} \mathrm{MnO}_{2} \cdot n \mathrm{H}_{2} \mathrm{O} \quad\left(c-\mathrm{K}_{x} \mathrm{MnO}_{2}\right)$ cathode integrated on interdigital-patterned nanoporous $\mathrm{Au}$ current microcollectors (V-Mn) to store/deliver charge with volumetric energy of $\sim 103 \mathrm{mWh} \mathrm{cm}^{-3}$ (14-fold higher than that of $4 \mathrm{~V}-500 \mu \mathrm{Ah}$ thinfilm lithium battery) at electrical power comparable to carbonbased microsupercapacitors. Meanwhile, these V-Mn AR-PMIBs exhibit a long-term cycling stability because the large interlayer spacing can effectively relieve volume expansion/contraction during the insertion/extraction of hydrated $\mathrm{K}^{+}$. The superior electrochemical properties make them promising candidates as micropower sources to complement other energy conversion devices such as commercial solar cells.

\section{Results}

Preparation and structural characterizations. Our fabrication strategy of $\mathrm{NP} \mathrm{Au} / a c-\mathrm{K}_{x} \mathrm{~V}_{2} \mathrm{O}_{5}$ microelectrodes is to electrodeposit the hydrated amorphous $\mathrm{K}_{x} \mathrm{~V}_{2} \mathrm{O}_{5} \cdot n \mathrm{H}_{2} \mathrm{O}\left(a-\mathrm{K}_{x} \mathrm{~V}_{2} \mathrm{O}_{5}\right)$ on one polarity of interdigital-patterned NP Au current microcollectors, followed by an annealing procedure that triggers the amorphous/ crystalline dual-phase nanostructuring of the constituent $a$ $\mathrm{K}_{x} \mathrm{~V}_{2} \mathrm{O}_{5}$ via removing some crystal water sandwiched between $\mathrm{V}_{2} \mathrm{O}_{5}$ bilayers. Hereinto, the $a c-\mathrm{K}_{x} \mathrm{~V}_{2} \mathrm{O}_{5}$ not only creates new ion diffusion pathways and accommodation sites but keeps the large interface spacing of crystalline $\mathrm{V}_{2} \mathrm{O}_{5}$ bilayers $(\sim 10.8 \AA)$ by making use of amorphous $\mathrm{K}_{0.25} \mathrm{~V}_{2} \mathrm{O}_{5} \cdot n \mathrm{H}_{2} \mathrm{O}$ as molecular pillars. This unique nanoarchitecture is expected to substantially facilitate the intercalation of guest hydrated $\mathrm{K}^{+}$cations in the $a c$ $\mathrm{K}_{x} \mathrm{~V}_{2} \mathrm{O}_{5}$ (Fig. 1a), in sharp contrast with the $\mathrm{K}^{+}$-free $a c-\mathrm{V}_{2} \mathrm{O}_{5}$ that undergoes atrocious volume change and encounters sluggish diffusion kinetics due to the narrow interlayer spacing (Fig. 1b) ${ }^{38,40,41,43}$. Figure 1c illustrates a schematic of on-chip AR-PIMB full cells, which are monolithically constructed on glassy substrates by further integrating the $c-\mathrm{K}_{x} \mathrm{MnO}_{2}$ cathode on the other polarity of interdigital-patterned NP Au current microcollectors ( $\mathrm{NP} \mathrm{Au} / c-\mathrm{K}_{x} \mathrm{MnO}_{2}$ ), with aqueous electrolyte of $0.5 \mathrm{M} \mathrm{K}_{2} \mathrm{SO}_{4}$. Therein, the current microcollectors built of $60 \mathrm{NP}$ $\mathrm{Au}$ interdigitated microelectrodes (30 electrodes per polarity) are produced by chemically dealloying $\mathrm{Ag}_{75} \mathrm{Au}_{25}$ (at\%) alloy precursor patterns with gaps of $\sim 50 \mu \mathrm{m}$ in $\mathrm{HNO}_{3}$ solution (Fig. 1d ${ }^{46}$. Each NP Au microelectrode has a 3D and bicontinuous nanoporous structure consisting of quasi-periodic Au ligaments and nanopore channels with a characteristic length of $\sim 70 \mathrm{~nm}$ (Supplementary Fig. 1) ${ }^{46}$. Representative cross-sectional scanning electron microscope (SEM) images of AR-PIMB microelectrodes, i.e. the NP $\mathrm{Au} / a c-\mathrm{K}_{x} \mathrm{~V}_{2} \mathrm{O}_{5}$ anode (Fig. 1e) and the $\mathrm{NP} \mathrm{Au} / c-\mathrm{K}_{x} \mathrm{MnO}_{2}$ cathode (Fig. 1f), demonstrate that both the electroactive materials are uniformly grown onto $\sim 750-\mathrm{nm}$ thick nanoporous skeleton along Au ligaments.

The crystallographic structures of the constituent $a c-\mathrm{K}_{x} \mathrm{~V}_{2} \mathrm{O}_{5}$ are controlled by annealing treatment of the as-electrodeposited $a-\mathrm{K}_{x} \mathrm{~V}_{2} \mathrm{O}_{5}$ precursors, in which the hydrated $\mathrm{K}^{+}$cations with various components $(x=0,0.1,0.2$, and 0.25$)$ are introduced by tuning $\mathrm{K}^{+}$concentrations in the electrolytes (Supplementary 
a

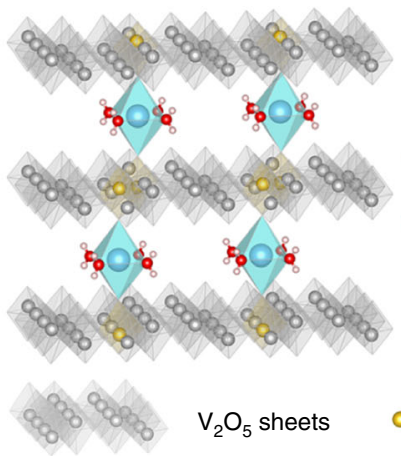

C

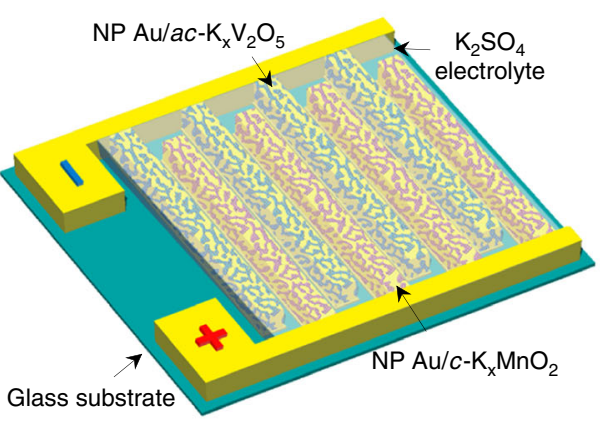

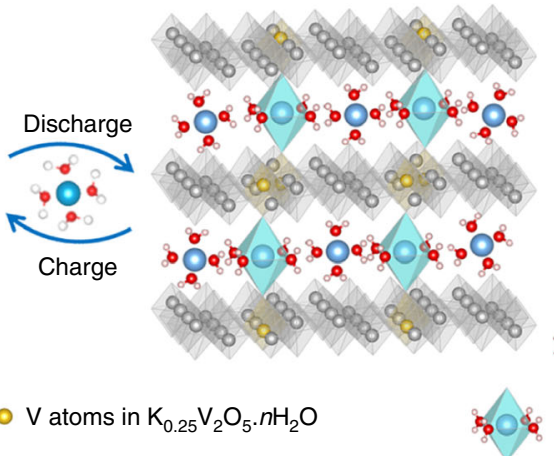

d

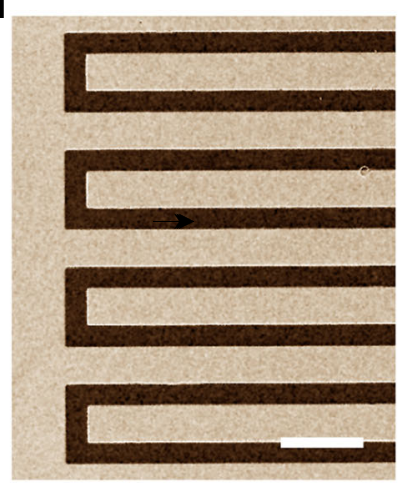

b

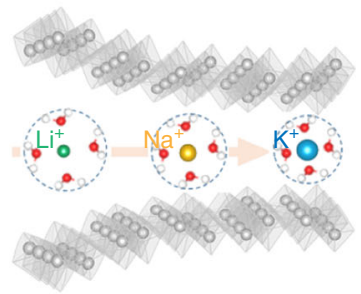

Guest hydrated $\mathrm{K}^{+}$cations

Hydrated $\mathrm{K}^{+}$in $\mathrm{K}_{0.25} \mathrm{~V}_{2} \mathrm{O}_{5} \cdot n \mathrm{H}_{2} \mathrm{O}$

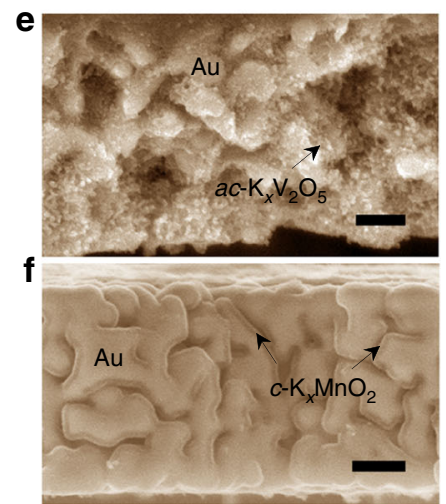

Fig. 1 Schematic and microstructures of aqueous $\mathrm{K}^{+}$ion microbatteries. $\mathbf{a}, \mathbf{b}$ Schematic diagrams illustrating the storage of hydrated ions in layered vanadium oxides: a ac- $\mathrm{K}_{x} \mathrm{~V}_{2} \mathrm{O}_{5}$ with a large interlayer spacing supported by $\mathrm{K}_{0.25} \mathrm{~V}_{2} \mathrm{O}_{5} \cdot n \mathrm{H}_{2} \mathrm{O}$ molecular pillars anchored between $\mathrm{V}_{2} \mathrm{O}_{5}$ bilayers, and b orthorhombic $\mathrm{V}_{2} \mathrm{O}_{5}$ with a small interlayer spacing that substantially restricts the intercalation of hydrated $\mathrm{Li}^{+}, \mathrm{Na}^{+}$, and $\mathrm{K}^{+}$cations. c Schematic illustration of aqueous $\mathrm{K}^{+}$-ion microbatteries, which are constructed by integrating $a c-\mathrm{K}_{x} \mathrm{~V}_{2} \mathrm{O}_{5}$ anode and $c-\mathrm{K}_{x} \mathrm{MnO}_{2}$ cathode on interdigitated nanoporous Au current collectors. $\mathbf{d}$ Low-magnification SEM image of interdigital-patterned nanoporous Au current collectors. e, $\mathbf{f}$ Cross-sectional SEM images for both anode and cathode of $\mathrm{K}^{+}$-ion microbatteries. The anode (e) and cathode (f) are composed of layered $\mathrm{K}_{x} \mathrm{~V}_{2} \mathrm{O}_{5}$ and $\mathrm{K}_{x} \mathrm{MnO}_{2}$ supported by nanoporous $\mathrm{Au}$ current collectors, respectively. Scale bar, $200 \mu \mathrm{m}(\mathbf{d}), 200 \mathrm{~nm}(\mathbf{e}, \mathbf{f})$

Fig. 2, Supplementary Table 1). Along thermogravimetric analysis (TGA) and differential scanning calorimetry (DSC) behaviors (Supplementary Fig. 3), the NP Au/ $a-\mathrm{K}_{x} \mathrm{~V}_{2} \mathrm{O}_{5}$ microelectrodes are annealed at 25,200 , and $300{ }^{\circ} \mathrm{C}$ for $12 \mathrm{~h}$, respectively, wherein a crystallization phenomenon occurs with successively removing crystal water and structure water. As shown in X-ray diffraction (XRD) patterns for the representative $a-\mathrm{K}_{x} \mathrm{~V}_{2} \mathrm{O}_{5} \quad(x=0.25)$ annealed at $200{ }^{\circ} \mathrm{C}$ (Fig. 2a), there appear characteristic diffraction peaks corresponding to (101), (110), and (301) planes of the layer-structured $o-\mathrm{V}_{2} \mathrm{O}_{5}$ (JCPDS 41-1426) ${ }^{40,44,47}$, apart from the bump one at $2 \theta=8.16^{\circ}$ due to the (100) plane of the layered $a$ $\mathrm{K}_{x} \mathrm{~V}_{2} \mathrm{O}_{5}(x=0.25)^{37}$. This implies the presence of amorphous/ crystalline dual-phase nanostructure in the $a c-\mathrm{K}_{x} \mathrm{~V}_{2} \mathrm{O}_{5}$ with a interlayer spacing of $\sim 10.8 \AA$, the value that is almost the same as that of the $a-\mathrm{K}_{x} \mathrm{~V}_{2} \mathrm{O}_{5}(x=0.25)$ (Table 1). Typical high-resolution transmission electron microscope (HRTEM) image (Fig. 2c) with evident crystalline and amorphous fast Fourier transform (FFT) patterns (Fig. 2d, e) compellingly evidences the unique dual-phase nanostructure, in which the amorphous nanodomains are embedded in the crystalline $o-\mathrm{V}_{2} \mathrm{O}_{5}$ matrix. Meanwhile, the ac$\mathrm{K}_{x} \mathrm{~V}_{2} \mathrm{O}_{5}$ displays the same characteristic Raman bands as the $a$ $\mathrm{K}_{x} \mathrm{~V}_{2} \mathrm{O}_{5}$ with the fingerprints of layer-type structure: the skeleton bent vibration at $163 \mathrm{~cm}^{-1}$ and the stretching vibration of vanadyl $\mathrm{V}=\mathrm{O}$ at $1015 \mathrm{~cm}^{-1}$, attesting that it keeps the layered structure (Supplementary Fig. 4$)^{48,49}$. When further increasing the annealing temperature to $300{ }^{\circ} \mathrm{C}$, the $a-\mathrm{K}_{x} \mathrm{~V}_{2} \mathrm{O}_{5}$ is completely transformed into a crystalline mixture composed of the $o-\mathrm{V}_{2} \mathrm{O}_{5}$ and the monoclinic $\mathrm{K}_{0.25} \mathrm{~V}_{2} \mathrm{O}_{5}\left(m-\mathrm{K}_{0.25} \mathrm{~V}_{2} \mathrm{O}_{5}\right)$. As demonstrated by XRD patterns for the crystalline $\mathrm{K}_{x} \mathrm{~V}_{2} \mathrm{O}_{5}\left(c-\mathrm{K}_{x} \mathrm{~V}_{2} \mathrm{O}_{5}\right)$, the additional diffraction peaks are ascribed to the (100), (002), (004), and (300) planes of the $m-\mathrm{K}_{0.25} \mathrm{~V}_{2} \mathrm{O}_{5}$ (JCPDS 39-0889) (Fig. 2a). Supplementary Figure $4 \mathrm{c}$ schematically illustrates the atomic structure of the $m-\mathrm{K}_{0.25} \mathrm{~V}_{2} \mathrm{O}_{5}$, where the $\left[\mathrm{V}_{4} \mathrm{O}_{12}\right]_{n}$ sheets consisting of $\mathrm{V}(1) \mathrm{O}_{6}$ and $\mathrm{V}(2) \mathrm{O}_{6}$ octahedra zigzag chains are linked by oxygen atoms to form $2 \mathrm{D}$ layered structure along the (001) plane, with $\mathrm{K}^{+}$cations intercalating between the layers. The $\left[\mathrm{V}_{4} \mathrm{O}_{12}\right]_{n}$ layers are further connected by $\mathrm{V}(3) \mathrm{O}_{5}$ and edgesharing oxygen atoms to form a $3 \mathrm{D}$ tunnel structure ${ }^{50}$. Figure $2 \mathrm{f}$ shows the typical HRTEM image of the $c-\mathrm{K}_{x} \mathrm{~V}_{2} \mathrm{O}_{5}$, where the interplanar distances of 0.23 and $0.21 \mathrm{~nm}$ correspond to the lattice planes of the $m-\mathrm{K}_{0.25} \mathrm{~V}_{2} \mathrm{O}_{5}(400)$ and the $o-\mathrm{V}_{2} \mathrm{O}_{5}(002)$ (Fig. $2 \mathrm{~g}$ ), respectively. In view that the layered $o-\mathrm{V}_{2} \mathrm{O}_{5}$ is the primary phase in the $c-\mathrm{K}_{x} \mathrm{~V}_{2} \mathrm{O}_{5}$ (Fig. 2a), the interlayer spacing is evaluated to be $\sim 4.42 \AA$ according to the (001) diffraction peak position of the $o-\mathrm{V}_{2} \mathrm{O}_{5}$ (Table 1$)^{38,40,44}$. In the structure evolution of the constituent $\mathrm{K}_{x} \mathrm{~V}_{2} \mathrm{O}_{5} \quad(x=0.25)$, X-ray photoelectron spectroscopy (XPS) analysis of oxygen-containing species justifies the change of water component sandwiched between the $\mathrm{V}_{2} \mathrm{O}_{5}$ bilayers. As shown in Fig. $2 \mathrm{~b}$ for high-resolution $\mathrm{O} 1 s \mathrm{XPS}$ spectra, there are three different oxygen species, i.e., the $\mathrm{O}^{2-}$ in the $\mathrm{V}_{2} \mathrm{O}_{5}$ lattice, the $\mathrm{OH}^{-}$, and the $\mathrm{H}_{2} \mathrm{O}$, to correspond to the peaks at the binding energies of $529.80,530.90$, and $533.01 \mathrm{eV}^{51}$. Compared with that in the pristine $a-\mathrm{K}_{x} \mathrm{~V}_{2} \mathrm{O}_{5}$ (left plot in Fig. $2 \mathrm{~b}$ ), the $\mathrm{O} 1 \mathrm{~s}$ peak of $\mathrm{H}_{2} \mathrm{O}$ gradually attenuates in the $a c-\mathrm{K}_{x} \mathrm{~V}_{2} \mathrm{O}_{5}$ (middle plot of Fig. 2b), and then disappears in the $c-\mathrm{K}_{x} \mathrm{~V}_{2} \mathrm{O}_{5}$ (right plot of Fig. 2b) due to the loss of crystal water and structure water, respectively. Similar crystalline phenomenon also occurs in the $\mathrm{K}^{+}$-free $a-\mathrm{V}_{2} \mathrm{O}_{5}$ to generate the $a c-\mathrm{V}_{2} \mathrm{O}_{5}$, but with a interlayer 
a

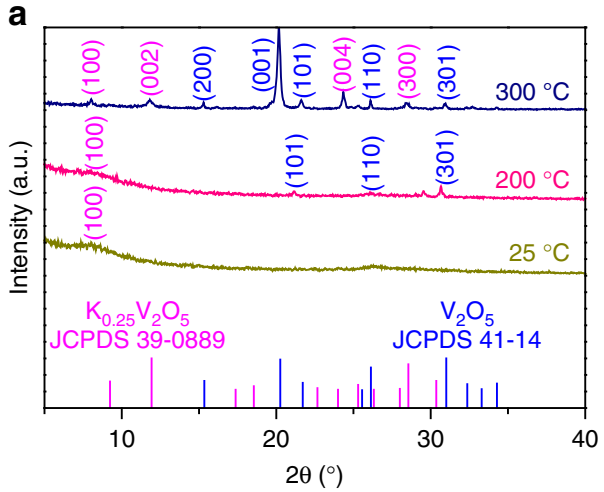

C

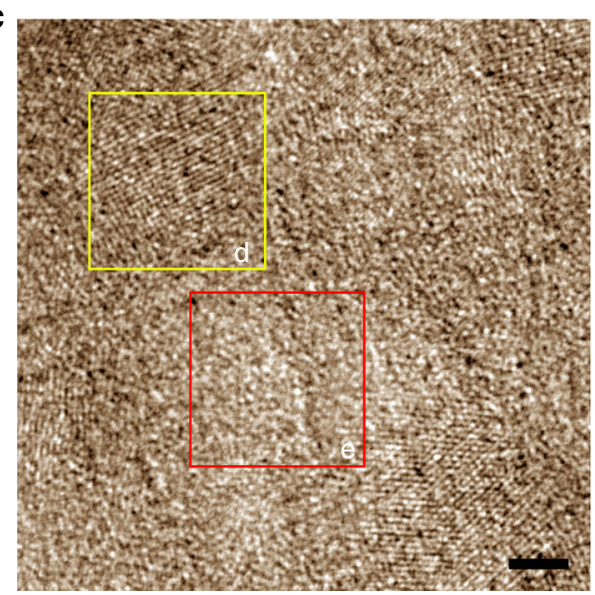

b

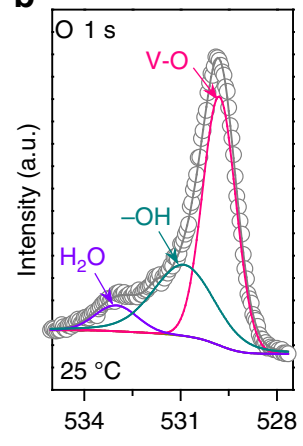

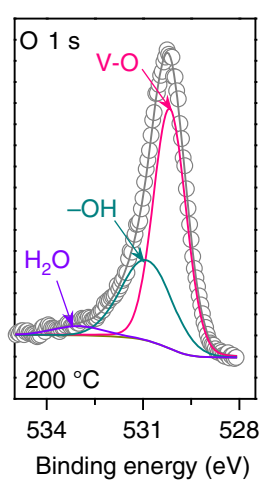

d

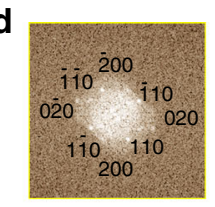

e
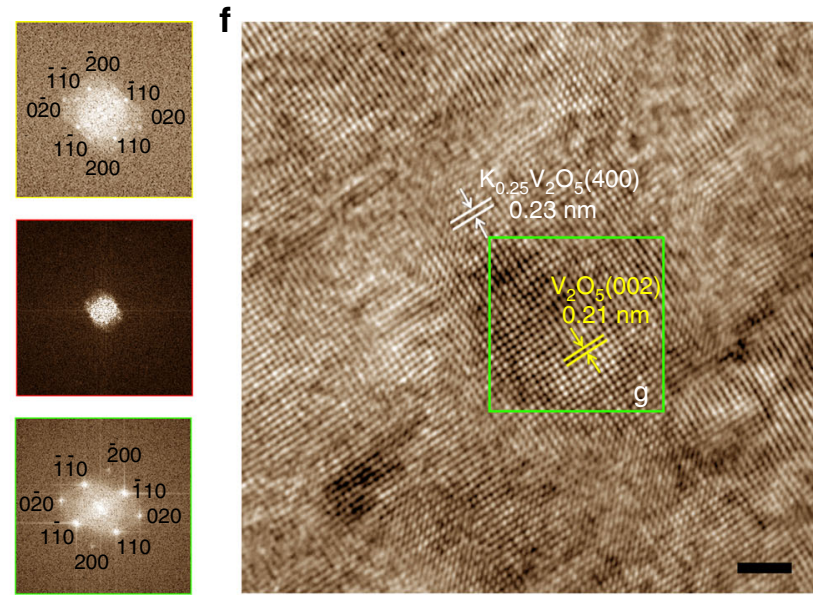

Fig. 2 Microstructural characterization of the constituent $\mathrm{K}_{x} \mathrm{~V}_{2} \mathrm{O}_{5}$. a XRD patterns of layered $\mathrm{K}_{x} \mathrm{~V}_{2} \mathrm{O}_{5}(x=0.25)$ that is annealed at 25,200 , and $300{ }^{\circ} \mathrm{C}$. The line patterns show reference cards 39-0889 and 41-1426 for layered $\mathrm{K}_{0.25} \mathrm{~V}_{2} \mathrm{O}_{5}$ and $\mathrm{V}_{2} \mathrm{O}_{5}$ according to JCPDS. b High-resolution XPS spectra of $\mathrm{O} 1 \mathrm{~s}$ in the layered $\mathrm{K}_{x} \mathrm{~V}_{2} \mathrm{O}_{5}(x=0.25)$ that is annealed at 25,200 , and $300^{\circ} \mathrm{C}$. c HRTEM image of the layered $\mathrm{K}_{x} \mathrm{~V}_{2} \mathrm{O}_{5}(x=0.25)$ with a dual-phase nanostructure that is produced by annealing at $200^{\circ} \mathrm{C}$. d, e FFT patterns of layered $\mathrm{K}_{x} \mathrm{~V}_{2} \mathrm{O}_{5}$ with crystalline region (yellow box) (d) and amorphous region (red box) (e). $\mathbf{f}$ HRTEM image of the layered $\mathrm{K}_{x} \mathrm{~V}_{2} \mathrm{O}_{5}(x=0.25)$ with a complete crystallization at annealing temperature of $300{ }^{\circ} \mathrm{C} . \mathbf{g} \mathrm{FFT}$ pattern of layered crystalline $\mathrm{K}_{x} \mathrm{~V}_{2} \mathrm{O}_{5}$ (green box). Scale bar, $2 \mathrm{~nm}(\mathbf{c}, \mathbf{f})$

Table 1 XRD and electrochemical results of layered $\mathrm{K}_{x} \mathrm{~V}_{2} \mathrm{O}_{5}$ and $\mathrm{V}_{2} \mathrm{O}_{5}$ supported by nanoporous Au current microcollectors

\begin{tabular}{|c|c|c|c|c|c|c|}
\hline Materials & Interlayer space $(\AA)$ & Capacity (mAh cm $\left.{ }^{-3}\right)$ & $R_{\mathbf{I}}(\Omega)$ & $R_{\mathrm{CT}}(\Omega)$ & $R_{\mathrm{IR}}(\Omega)$ & $Z_{W}\left(S s^{1 / 2}\right)$ \\
\hline$a-\mathrm{K}_{0.25} \mathrm{~V}_{2} \mathrm{O}_{5}$ & 10.96 & 370 & 8.99 & 1.19 & 10.6 & 892.9 \\
\hline$c-\mathrm{K}_{0.25} \mathrm{~V}_{2} \mathrm{O}_{5}$ & 4.42 & 500 & 10.79 & 2.19 & 16.1 & 741.9 \\
\hline$a c-\mathrm{K}_{0.25} \mathrm{~V}_{2} \mathrm{O}_{5}$ & 10.83 & 717 & 5.53 & 0.28 & 6.6 & 3358.7 \\
\hline$a c-\mathrm{K}_{0.1} \mathrm{~V}_{2} \mathrm{O}_{5}$ & 5.33 & 464 & 5.77 & 0.61 & 7.8 & 1949.1 \\
\hline$a c-\mathrm{V}_{2} \mathrm{O}_{5}$ & 4.36 & 242 & 19.97 & 0.94 & 21.8 & 1194.9 \\
\hline
\end{tabular}

spacing directly decreasing to $4.36 \AA$ as a consequence of squeezing out the crystal water at $200^{\circ} \mathrm{C}$ (Table 1, Supplementary Figs. 5, 6) $38,40,44$. This observation is in sharp contrast with the ac- $\mathrm{K}_{x} \mathrm{~V}_{2} \mathrm{O}_{5}$, demonstrating the significant role of the amorphous $\mathrm{K}_{0.25} \mathrm{~V}_{2} \mathrm{O}_{5} \cdot n \mathrm{H}_{2} \mathrm{O}$ as molecular pillars in maintaining large interlayer spacing. Owing to the decrease of the hydrated $\mathrm{K}^{+}$ pillars, the interlayer spacing of $a c-\mathrm{K}_{x} \mathrm{~V}_{2} \mathrm{O}_{5}$ decreases with the $\mathrm{K}^{+}$ concentration (Table 1, Supplementary Fig. 7).

Electrochemical characterizations. The electrochemical measurements of $\mathrm{NP} \mathrm{Au} / \mathrm{K}_{x} \mathrm{~V}_{2} \mathrm{O}_{5}$ microelectrodes are performed in 0.5 $\mathrm{M} \mathrm{K}_{2} \mathrm{SO}_{4}$ aqueous electrolyte on the basis of a three-electrode configuration with a $\mathrm{Pt}$ foil as the counter electrode and an $\mathrm{Ag} /$ $\mathrm{AgCl}$ electrode as the reference electrode. Figure 3a shows typical cyclic voltammograms (CVs) of $\mathrm{NP} \quad \mathrm{Au} / \mathrm{K}_{x} \mathrm{~V}_{2} \mathrm{O}_{5} \quad(x=0.25)$ microelectrodes within a voltage window of -0.8 to $0 \mathrm{~V}$ (versus
$\mathrm{Ag} / \mathrm{AgCl}$ ) at a scan rate of $50 \mathrm{mV} \mathrm{s}{ }^{-1}$. Relative to $\mathrm{NP} \mathrm{Au} / a-\mathrm{K}_{x} \mathrm{~V}_{2} \mathrm{O}_{5}$ and $\mathrm{NP} \mathrm{Au} / c-\mathrm{K}_{x} \mathrm{~V}_{2} \mathrm{O}_{5}$, the NP $\mathrm{Au} / a c-\mathrm{K}_{x} \mathrm{~V}_{2} \mathrm{O}_{5}$ exhibits remarkably enhanced current density because of the unique dual-phase nanostructure of the constituent $a c-\mathrm{K}_{x} \mathrm{~V}_{2} \mathrm{O}_{5}$, which offers more room to accommodate guest hydrated $\mathrm{K}^{+}$cations and facilitate their solid-state diffusion kinetics in the pillar supported interlayer space. Associated with the nanoporous Au current microcollectors that enables the constituent $a c-\mathrm{K}_{x} \mathrm{~V}_{2} \mathrm{O}_{5}$ to be sandwiched between highly conductive ion and electron transport pathways, the $\mathrm{CV}$ curves at various scan rates from 5 to $1000 \mathrm{mV} \mathrm{s}^{-1}$ retain a quasirectangular shape, indicating the exceptional high-rate capability of $\mathrm{NP} \mathrm{Au} / a c-\mathrm{K}_{x} \mathrm{~V}_{2} \mathrm{O}_{5}$ (Supplementary Fig. 8a, b). Although both NP $\mathrm{Au} / a-\mathrm{K}_{x} \mathrm{~V}_{2} \mathrm{O}_{5}$ and NP Au/c- $\mathrm{K}_{x} \mathrm{~V}_{2} \mathrm{O}_{5}$ microelectrodes also benefit from such microelectrode architecture with fast electron and ion transports, they encounter rate-limited electrochemical energystorage behaviors due to the poor accessibility and diffusion of 

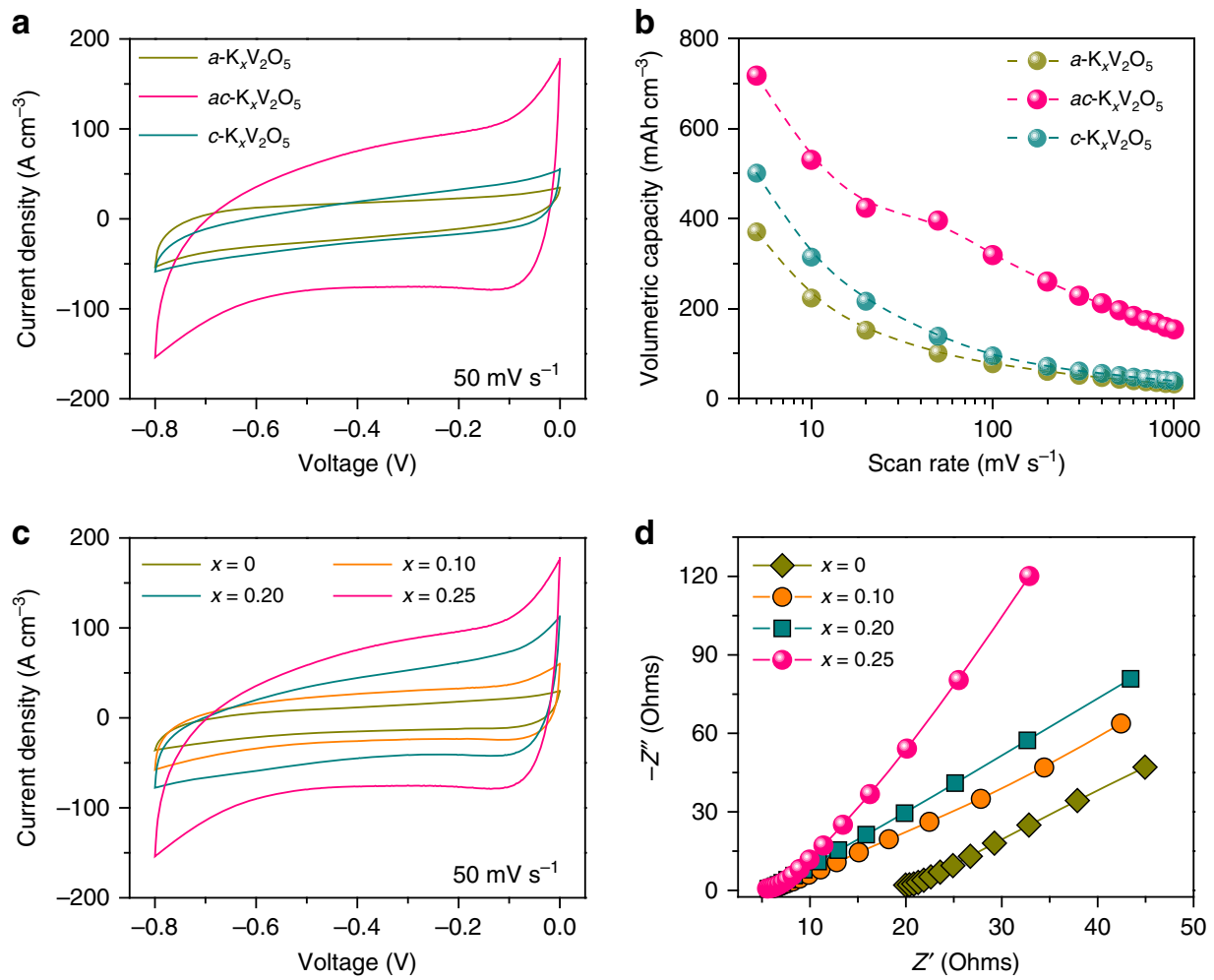

Fig. 3 Electrochemical characterization of anodic nanoporous $\mathrm{Au} / \mathrm{K}_{x} \mathrm{~V}_{2} \mathrm{O}_{5}$ microelectrodes. a Representative $\mathrm{CV}$ curves of nanoporous Au supported a$\mathrm{K}_{x} \mathrm{~V}_{2} \mathrm{O}_{5}, a c-\mathrm{K}_{x} \mathrm{~V}_{2} \mathrm{O}_{5}$, and $c-\mathrm{K}_{x} \mathrm{~V}_{2} \mathrm{O}_{5}(x=0.25)$ microelectrodes that are annealed at 25,200 , and $300{ }^{\circ} \mathrm{C}$, respectively. Scan rate: $50 \mathrm{mV} \mathrm{s}^{-1}$; electrolyte: $0.5 \mathrm{M} \mathrm{K}_{2} \mathrm{SO}_{4}$. b Volumetric capacities of nanoporous $\mathrm{Au} / \mathrm{K}_{x} \mathrm{~V}_{2} \mathrm{O}_{5}(x=0.25)$ microelectrodes with the constituent $a-\mathrm{K}_{x} \mathrm{~V}_{2} \mathrm{O}_{5}, a c-\mathrm{K}_{x} \mathrm{~V}_{2} \mathrm{O}_{5}$, and c- $\mathrm{K}_{x} \mathrm{~V}_{2} \mathrm{O}_{5}$ (annealed at 25,200 , and $300^{\circ} \mathrm{C}$ ) at various scan rates from 5 to $1000 \mathrm{mV} \mathrm{s}^{-1}$. c Representative $\mathrm{CV}$ curves of nanoporous $\mathrm{Au} / a c-\mathrm{K}_{x} \mathrm{~V}_{2} \mathrm{O}_{5}(x=0,0.1,0.2$, and 0.25$)$ microelectrodes that are annealed at $200^{\circ} \mathrm{C}$. scan rate: $50 \mathrm{mV} \mathrm{s}^{-1}$; electrolyte: $0.5 \mathrm{M} \mathrm{K}_{2} \mathrm{SO}_{4}$. $\mathbf{d}$ ElS spectra of nanoporous Au/ac-K $\mathrm{V}_{2} \mathrm{O}_{5}(x=0$, $0.1,0.2$, and 0.25 ) microelectrodes annealed at $200^{\circ} \mathrm{C}$

hydrated $\mathrm{K}^{+}$cations in the constituent electroactive materials, i.e., the $a-\mathrm{K}_{x} \mathrm{~V}_{2} \mathrm{O}_{5}$, in which too much crystal water fills in large interlayer spacing, and the $c-\mathrm{K}_{x} \mathrm{~V}_{2} \mathrm{O}_{5}$, of which the interlayer spacing is too narrow (Supplementary Fig. $8 \mathrm{c}, \mathrm{d}$ ). As a result, they exhibit much lower volumetric capacities than the NP Au/ac$\mathrm{K}_{x} \mathrm{~V}_{2} \mathrm{O}_{5}$ at various scan rates (Fig. $3 \mathrm{~b}$ ). Therein, the gravimetric capacity of the constituent $a c-\mathrm{K}_{x} \mathrm{~V}_{2} \mathrm{O}_{5}$ reaches $382 \mathrm{mAh} \mathrm{g}^{-1}$ at $5 \mathrm{mV} \mathrm{s}^{-1}$ and retains $81 \mathrm{mAh} \mathrm{g}^{-1}$ at $1000 \mathrm{mV} \mathrm{s}^{-1}$, outperforming the constituent $a-\mathrm{K}_{x} \mathrm{~V}_{2} \mathrm{O}_{5}$ and $c-\mathrm{K}_{x} \mathrm{~V}_{2} \mathrm{O}_{5}$ (Supplementary Fig. 9a), as well as some of the best $\mathrm{V}_{2} \mathrm{O}_{5}$-based electrode materials in a full rate range reported previously for aqueous energy storage (Supplementary Fig. 9b). Electrochemical impedance spectroscopy (EIS) analysis in a frequency ranging from $100 \mathrm{kHz}$ to $10 \mathrm{mHz}$ demonstrates that the outstanding energy storage/delivery behavior of the constituent $a c-\mathrm{K}_{x} \mathrm{~V}_{2} \mathrm{O}_{5}$ results from the enhanced intercalation kinetics of hydrated $\mathrm{K}^{+}$cations in the dual-phase nanostructure. In the Nyquist plot, the EIS spectrum displays a quasi-semicircle with a ultrasmall diameter in the high- and middle-frequency ranges, followed by inclined lines in the low-frequency range (Supplementary Fig. 10a). At very high frequencies, the intercept at the real part represents the ohmic resistance $\left(R_{\mathrm{I}}\right)$ of the electrolyte and the intrinsic resistance of microelectrode; the semicircular behavior in the middlefrequency range corresponds to the charge transfer resistance $\left(R_{\mathrm{CT}}\right)$ and the double-layer capacitance $\left(C_{\mathrm{F}}\right)$; the slope of the inclined line at the low frequencies is the Warburg resistance $\left(Z_{\mathrm{w}}\right)$, which is a result of the frequency dependence of ion diffusion/transport inside the electrode. Using the complex nonlinear least-squares fitting method (Supplementary Fig. 10b), the $\mathrm{NP} \mathrm{Au} / a c-\mathrm{K}_{x} \mathrm{~V}_{2} \mathrm{O}_{5}$ is revealed to exhibit the lowest equivalent series resistances $\left(R_{\mathrm{I}}=5.53 \Omega\right.$ and $\left.R_{\mathrm{CT}}=0.28 \Omega\right)$ (Supplementary Fig. 10c) and the highest $Z_{\mathrm{w}}$ value $\left(3358 \mathrm{~S} \mathrm{~s}^{1 / 2}\right.$ ) (Supplementary Fig. 10d), reflecting the superior ion accessibility/diffusion and charge transfer in the dual-phase nanostructure during the electrochemical energy storage. The distinguished electrochemical behavior of the NP $\mathrm{Au} / a c-\mathrm{K}_{x} \mathrm{~V}_{2} \mathrm{O}_{5}$ microelectrode is further elucidated by charge/discharge kinetics analysis with an assumption that the current density $(i)$ obeys a power-law relationship with the scan rate $(v)^{52,53}$, namely $i=a v^{b}$, where $a$ is an adjustable parameter, the $b$ value of 0.5 or 1 represents a diffusion- or surface-controlled process, respectively. In the $\ln (i)-\ln$ (v) plots (Supplementary Fig. 8e), the $b$ value of the NP Au/ac$\mathrm{K}_{x} \mathrm{~V}_{2} \mathrm{O}_{5}$ is determined to be 0.86 due to enhanced insertion/ extraction kinetics of the hydrated $\mathrm{K}^{+}$cations, in contrast with those of the NP Au/ $a-\mathrm{K}_{x} \mathrm{~V}_{2} \mathrm{O}_{5}(0.60)$ and NP Au/c- $\mathrm{K}_{x} \mathrm{~V}_{2} \mathrm{O}_{5}(0.64)$ with evident limitations of poor accessibility and slow diffusion.

Figure $3 \mathrm{c}$ and Supplementary Fig. 11a-d compare the CV curves of $\mathrm{NP} \mathrm{Au} / a c-\mathrm{K}_{x} \mathrm{~V}_{2} \mathrm{O}_{5}$ microelectrodes, of which the constituent $a c-\mathrm{K}_{x} \mathrm{~V}_{2} \mathrm{O}_{5}$ has $\mathrm{K}^{+}$components changed from 0 to 0.25 , at various scan rates. Owing to the maintenance of amorphous nanodomains of $\mathrm{K}_{0.25} \mathrm{~V}_{2} \mathrm{O}_{5} \cdot n \mathrm{H}_{2} \mathrm{O}$ in the constituent $a c-\mathrm{K}_{x} \mathrm{~V}_{2} \mathrm{O}_{5}$, the $\mathrm{NP} \mathrm{Au} / a c-\mathrm{K}_{x} \mathrm{~V}_{2} \mathrm{O}_{5}$ microelectrodes exhibit evidently improved current densities compared with the one with the constituent $\mathrm{K}^{+}$-free $a c-\mathrm{V}_{2} \mathrm{O}_{5}$, i.e., $\mathrm{NP} \mathrm{Au} / a c-\mathrm{V}_{2} \mathrm{O}_{5}$. Furthermore, the current density of $\mathrm{NP} A u / a c-\mathrm{K}_{x} \mathrm{~V}_{2} \mathrm{O}_{5}$ microelectrode increases with the increasing $x$ value, which enlists the $\mathrm{NP} \mathrm{Au} / a c-\mathrm{K}_{x} \mathrm{~V}_{2} \mathrm{O}_{5}$ with $x=0.25$ to achieve a volumetric capacity of as high as $\sim 715 \mathrm{mAh} \mathrm{cm}^{-3}$ at $5 \mathrm{mV} \mathrm{s}^{-1}$ (Fig. 3b), about threefold the value of $\mathrm{NP} \mathrm{Au} / a c-\mathrm{V}_{2} \mathrm{O}_{5} \quad\left(\sim 242 \mathrm{mAh} \mathrm{cm}^{-3}\right)$ (Supplementary Fig. 11e, f). Even when increasing the scan rate 

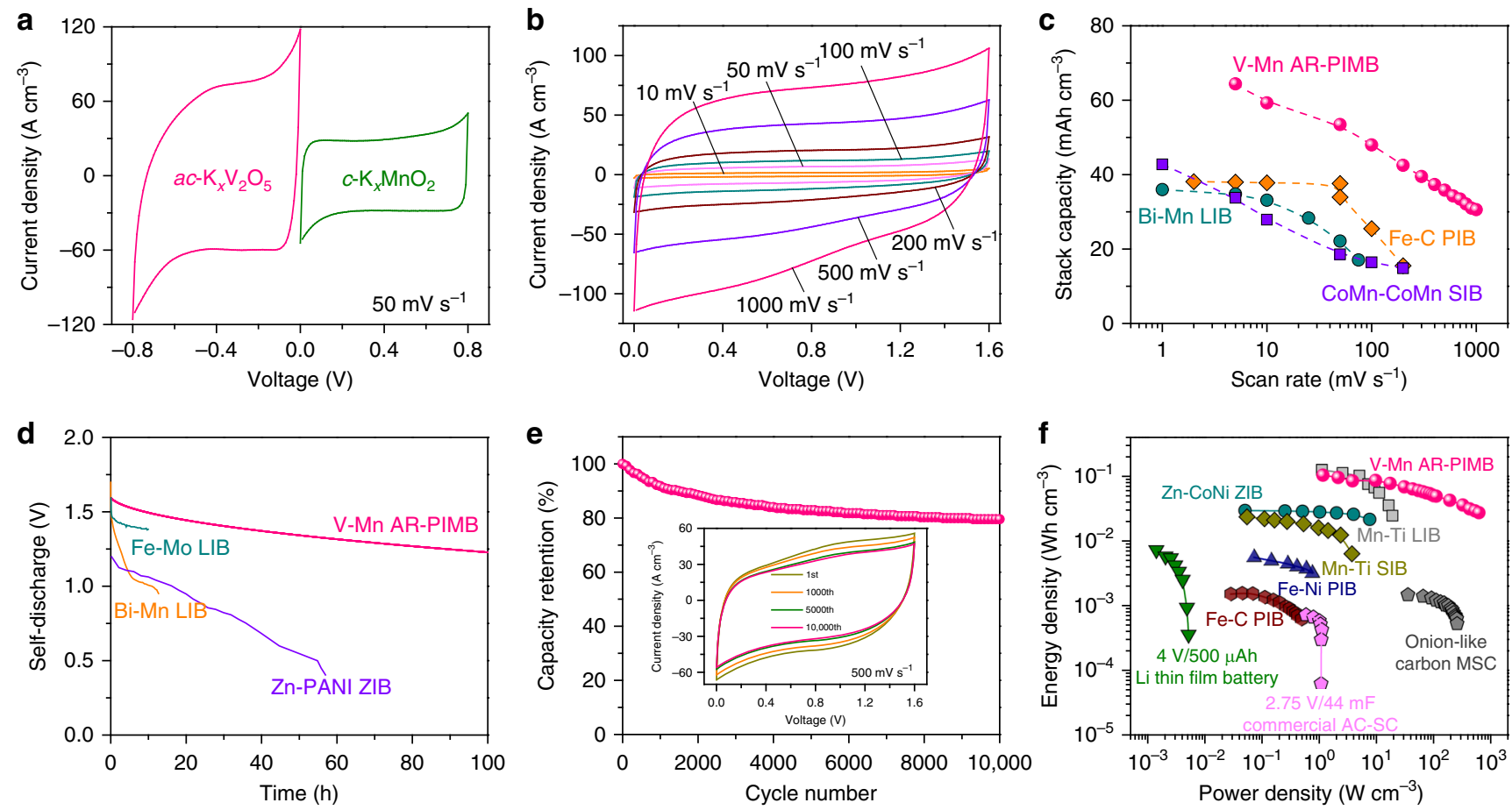

Fig. 4 Electrochemical performance of $V-M n$ AR-PIMBs. a Representative $C V$ curves for single electrode of $\mathrm{K}_{x} \mathrm{~V}_{2} \mathrm{O}_{5}(x=0.25)$ anode and $\mathrm{K}_{x} \mathrm{MnO}_{2}(x=$ 0.23 ) cathode supported by nanoporous gold current collector in the voltage window of -0.8 to 0 and $0-0.8 \mathrm{~V}$ at a scan rate of $50 \mathrm{mV} \mathrm{s}^{-1}$ in $0.5 \mathrm{M} \mathrm{K}_{2} \mathrm{SO}_{4}$. b $C V$ curves at various scan rates for aqueous $V-M n A R-P I M B s$ that are constructed with $\mathrm{K}_{x} \mathrm{~V}_{2} \mathrm{O}_{5}$ and $\mathrm{K}_{x} \mathrm{MnO}_{2}$ on nanoporous gold current collectors as anode and cathode. Voltage window is extended to $1.6 \mathrm{~V}$ in aqueous electrolyte of $0.5 \mathrm{M} \mathrm{K}_{2} \mathrm{SO}_{4}$. c Stack capacity of aqueous V-Mn AR-PIMBs at various scan rates, comparing with previously reported rechargeable aqueous alkaline-metal-ion batteries, such as $\mathrm{K}^{+}$-ion batteries with carbon-encapsulated $\mathrm{Fe}_{3} \mathrm{O}_{4}$ nanorod array anode and carbon nanotube film cathode in $3 \mathrm{M} \mathrm{KOH}$ electrolyte $(\mathrm{Fe}-\mathrm{C} \mathrm{PIBs})^{56}$, $\mathrm{Li}^{+}$-ion batteries with $\mathrm{Bi}_{2} \mathrm{O}_{3}$ anode, and $\mathrm{LiMn}_{2} \mathrm{O}_{4}$ cathode in a mixed electrolyte of $\mathrm{Li}_{2} \mathrm{SO}_{4}$ and $\mathrm{LiCl}(\mathrm{Bi}-\mathrm{Mn} \mathrm{LIBs})^{57}$, and symmetric $\mathrm{Na}^{+}$-ion batteries of biphase cobalt-manganese oxide nanosheets in $0.1 \mathrm{M}$ $\mathrm{Na}_{2} \mathrm{SO}_{4}(\mathrm{CoMn}-\mathrm{CoMn} \mathrm{SIBs})^{21}$. d Comparison of self-discharge performance for aqueous $\mathrm{V}-\mathrm{Mn} \mathrm{AR}-\mathrm{PIMBs}$ with aqueous $\mathrm{Bi}_{-} \mathrm{Mn} \mathrm{LIBs}^{57}, \mathrm{LiFePO}_{4} / / \mathrm{Mo}_{6} \mathrm{~S}_{8}$ (Fe-Mo) LIB, and $\mathrm{Zn} / /$ polyaniline $\mathrm{Zn}^{2+}$-ion battery (Zn-PANI ZIB) ${ }^{58}$. e Cycling stability of aqueous $\mathrm{V}$-Mn $\mathrm{K}^{+}$-ion microbatteries at the scan rate of $500 \mathrm{mV} \mathrm{s}^{-1}$. Inset: Typical CV curves at different cycles. $\mathbf{f}$ Ragone plot comparing stack energy and power densities of $\mathrm{V}$-Mn AR-PIMB with commercially available $4 \mathrm{~V} / 500 \mu \mathrm{Ah}$ Li thin-film battery, $2.75 \mathrm{~V} / 44 \mathrm{mF}$ commercial activated carbon supercapacitors (AC-SC) ${ }^{9,14}$, Fe-C PIB ${ }^{56}$, carbon fiber supported $\mathrm{Fe}_{3} \mathrm{O}_{4} / / \mathrm{NiO}(\mathrm{Fe}-\mathrm{Ni}) \mathrm{PIB}, \mathrm{Na}_{0.44} \mathrm{MnO}_{2} / / \mathrm{NaTi}_{2}\left(\mathrm{PO}_{4}\right)_{3}(\mathrm{Mn}-\mathrm{Ti}) \mathrm{SIB}^{28}, \mathrm{Li}_{1.1} \mathrm{Mn}_{2} \mathrm{O}_{4} / / \mathrm{LiTi}_{2}\left(\mathrm{PO}_{4}\right)_{3}(\mathrm{Mn}-\mathrm{Ti}) \mathrm{LIB}$ and CoNi $(\mathrm{OH})_{2} / / \mathrm{Zn}(\mathrm{CoNi}-\mathrm{Zn}) \mathrm{ZIB} 59$, as well as onion-like carbon-based microsupercapacitors (onion-like carbon MSC) ${ }^{9}$

to $1000 \mathrm{mV} \mathrm{s}^{-1}$, it still retains the capacity of $153 \mathrm{mAh} \mathrm{cm}^{-3}$, which is more than six times higher than the NP $\mathrm{Au} / a c-\mathrm{V}_{2} \mathrm{O}_{5}$ (Supplementary Fig. 11e). These facts demonstrate the important roles of amorphous $\mathrm{K}_{0.25} \mathrm{~V}_{2} \mathrm{O}_{5} \cdot n \mathrm{H}_{2} \mathrm{O}$ nanodomains in improving energy-storage behaviors of the $a c-\mathrm{K}_{x} \mathrm{~V}_{2} \mathrm{O}_{5}$, i.e., serving as molecular pillars to support large interlayer spacing for facilitating the accessibility and diffusion of guest hydrated $\mathrm{K}^{+}$ cations $^{29,30}$, and acting as dopants to ameliorate the electronic conductivity of $\mathrm{V}_{2} \mathrm{O}_{5}$ bilayers for boosting electron transfer ${ }^{54,55}$. This is further demonstrated by their distinct EIS spectra in the Nyquist plots (Fig. 3d). As shown in Supplementary Fig. 12a, all the NP Au/ac- $\mathrm{K}_{x} \mathrm{~V}_{2} \mathrm{O}_{5}(x=0.10,0.20$, and 0.25$)$ microelectrodes have much lower intrinsic electrode resistances $\left(R_{\mathrm{I}}=\sim 5.5-5.7 \Omega\right)$ and charge transfer resistances $\left(R_{\mathrm{CT}}=\sim 0.28-0.61 \Omega\right)$ than the $\mathrm{NP} \mathrm{Au} / a c-\mathrm{V}_{2} \mathrm{O}_{5}\left(R_{\mathrm{I}}=\sim 19.9 \Omega\right.$ and $\left.R_{\mathrm{CT}}=\sim 0.94 \Omega\right)$, despite slight variations as a function of $\mathrm{K}^{+}$component. While for the Warburg slope reflecting the ion diffusion kinetics (Supplementary Fig. 12b), it increases with the component of the hydrated $\mathrm{K}^{+}$ pillars and reaches the highest value for the NP $\mathrm{Au} / a c-\mathrm{K}_{x} \mathrm{~V}_{2} \mathrm{O}_{5}$ $(x=0.25)$.

Electrochemical performance of microdevices. In view of the outstanding electrochemical properties of $\mathrm{NP} A u / a c-\mathrm{K}_{x} \mathrm{~V}_{2} \mathrm{O}_{5}$ $(x=0.25)$ microelectrodes, they are used as anodes to pair with the NP Au/c- $\mathrm{K}_{x} \mathrm{MnO}_{2}$ cathodes (Supplementary Fig. 13) to build full microcells of on-chip V-Mn AR-PIMBs when integrating the $c-\mathrm{K}_{x} \mathrm{MnO}_{2}$ on the other polarity of interdigitated NP Au current microcollectors (Fig. 1c-f). By virtue of the potential difference between the NP Au/ac- $\mathrm{K}_{x} \mathrm{~V}_{2} \mathrm{O}_{5}$ anode $(-0.8$ to $0 \mathrm{~V})$ and the NP $\mathrm{Au} / c-\mathrm{K}_{x} \mathrm{MnO}_{2}$ cathode $(0-0.8 \mathrm{~V})$ (Fig. $4 \mathrm{a}$ ), the working voltage window of full microcells is extended to $1.6 \mathrm{~V}$ in the aqueous electrolyte of $0.5 \mathrm{M} \mathrm{K}_{2} \mathrm{SO}_{4}$. Figure $4 \mathrm{~b}$ shows $\mathrm{CV}$ curves of the $\mathrm{V}-\mathrm{Mn}$ AR-PIMBs at various scan rates corresponding to a full charge or discharge time from $\sim 1.6 \mathrm{~s}$ to $\sim 5.3 \mathrm{~min}$, during which they are able to achieve a stack capacity of as high as $\sim 64 \mathrm{mAh} \mathrm{cm}^{-3}$ based on the total volume of the full microcells. About half of the stack capacity $\left(31 \mathrm{mAh} \mathrm{cm}^{-3}\right)$ can be retained at exceptionally high discharge rates of $1000 \mathrm{mV} \mathrm{s}^{-1}$ (namely, full discharge in less than $2 \mathrm{~s}$ ) (Fig. 4c). This exceptional rate performance enlists the V-Mn AR-PIMBs to outperform some of the best rechargeable aqueous metal-ion batteries reported previously: such as aqueous $\mathrm{K}^{+}$-ion batteries with carbonencapsulated $\mathrm{Fe}_{3} \mathrm{O}_{4}$ nanorod array anode and carbon nanotube film cathode in $3 \mathrm{M} \mathrm{KOH}$ electrolyte $(\mathrm{Fe}-\mathrm{C} \mathrm{PIBs})^{56}, \mathrm{Li}^{+}$-ion batteries with $\mathrm{Bi}_{2} \mathrm{O}_{3}$ anode, and $\mathrm{LiMn}_{2} \mathrm{O}_{4}$ cathode in a mixed electrolyte of $\mathrm{Li}_{2} \mathrm{SO}_{4}$ and $\mathrm{LiCl}(\mathrm{Bi}-\mathrm{Mn} \mathrm{LIBs})^{57}$, as well as symmetric $\mathrm{Na}^{+}$-ion batteries of biphase cobalt-manganese oxide nanosheets in $0.1 \mathrm{M} \mathrm{Na}_{2} \mathrm{SO}_{4}$ (CoMn-CoMn SIBs) ${ }^{21}$. Meanwhile, the V-Mn AR-PIMBs displays very low self-discharge, with less than $3.6 \mathrm{mV} \mathrm{h}^{-1}$, much better than LIBs assembled with $\mathrm{Mo}_{6} \mathrm{~S}_{8}$ 
a
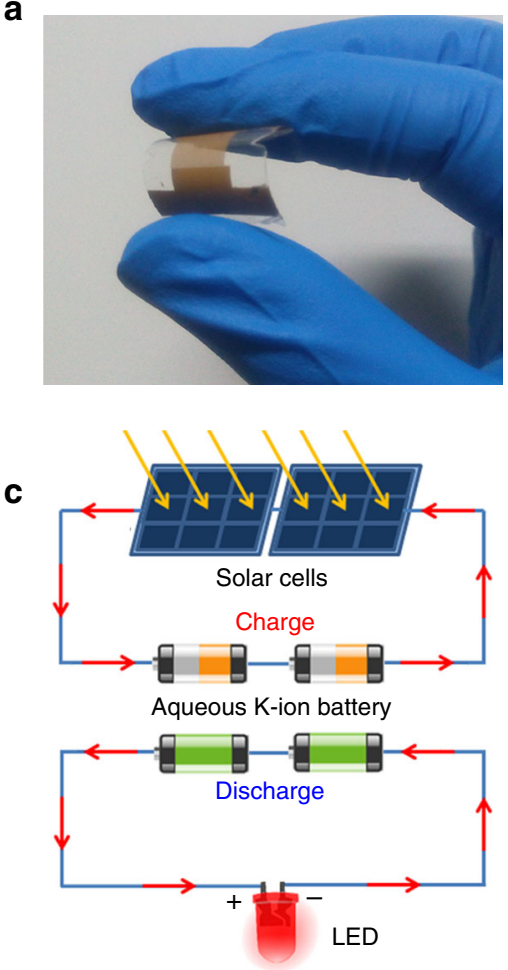

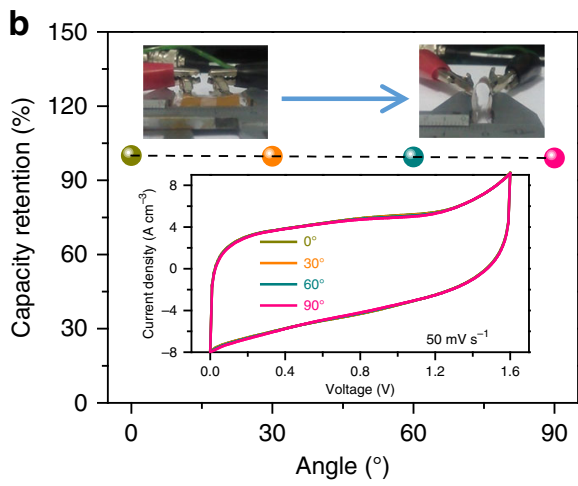

d

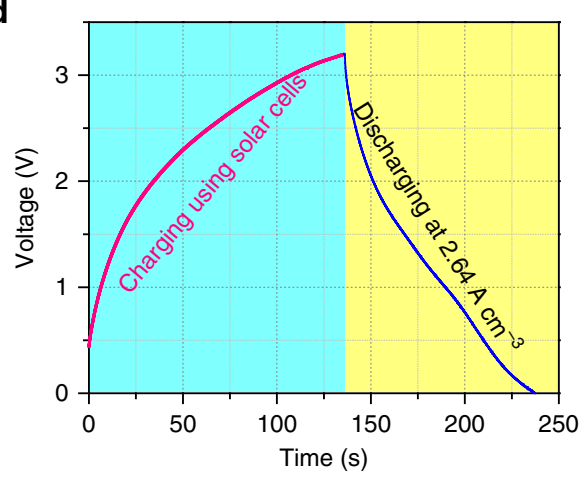

Fig. 5 Flexible all-solid-state V-Mn AR-PIMBs integrated in solar cells. a Typical photograph for flexible all-solid-state V-Mn AR-PIMBs supported by PMMA substrates with PVA/KCl gel electrolyte. b Capacity retention of flexible aqueous V-Mn AR-PIMBs at different macroscopic bend angles. Inset: Photographs of flexible all-solid-state $\mathrm{V}$-Mn $\mathrm{K}^{+}$-ion microbatteries bended from 0 to $90^{\circ}$ (top) and their corresponding CV curves (bottom). c Schematic showing a self-powered system constructed with two-series flexible $\mathrm{V}-\mathrm{Mn}$ AR-PIMBs, $2 \mathrm{~V}$ thin-film solar cells and LED lights: when sunlight is available, the V-Mn AR-PIMBs are charged by solar cells (top); when sunlight is unavailable, they are discharged to power LED lights (bottom). $\mathbf{d}$ Typical charge/ discharge curves for the charged process powered by solar cells and the discharge process at a current density of $2.64 \mathrm{~A} \mathrm{~cm}^{-3}$

anode and $\mathrm{LiFePO}_{4}$ cathode (Mo-Fe LIBs) in Li-TFSI: $\mathrm{H}_{2} \mathrm{O}=1$ $\left(21.1 \mathrm{mV} \mathrm{h}^{-1}\right), \mathrm{Bi}-\mathrm{Mn}$ LIBs $\left(58.9 \mathrm{mV} \mathrm{h}^{-1}\right)^{58}$, and $\mathrm{Zn}^{2+}$-ion batteries with $\mathrm{Zn}$ anode and polyaniline film cathode ( $\mathrm{Zn}-\mathrm{PANI}$ ZIBs) in $1 \mathrm{M} \mathrm{ZnCl}_{2}\left(12.7 \mathrm{mV} \mathrm{h}^{-1}\right)$ (Fig. $\left.4 \mathrm{~d}\right)$. Figure $4 \mathrm{e}$ shows that the cycling performance of the V-Mn AR-PIMB, which retains $80 \%$ of its initial capacity after $10,000 \mathrm{CV}$ cycles at a scan rate of $500 \mathrm{mV} \mathrm{s}^{-1}$ (inset of Fig. 4e), demonstrates the impressive longterm stability in the voltage window between 0 and $1.6 \mathrm{~V}$.

In the Ragone plot, Fig. $4 \mathrm{f}$ compares the stack-volumetric power and energy densities of V-Mn AR-PIMB with the values of commercially available devices including $4 \mathrm{~V} / 500 \mu \mathrm{Ah}$ Li thin-film battery and $2.75 \mathrm{~V} / 44 \mathrm{mF}$ activated carbon supercapacitors ${ }^{9,14}$. Our microbattery has a volumetric energy density of $\sim 103 \mathrm{mWh} \mathrm{cm}^{-3}$ based on the whole devices volume, which is 14-fold higher than $4 \mathrm{~V} / 500 \mu \mathrm{Ah}$ Li thin-film battery, when delivering at the electrical power $\left(1.2 \mathrm{~W} \mathrm{~cm}^{-3}\right)$ compared to $2.75 \mathrm{~V} / 44 \mathrm{mF}$ activated carbon supercapacitors. As a result of monolithic integration of on-chip V-Mn AR-PIMB constructed on 3D bicontinuous nanoporous $\mathrm{Au}$ current microcollectors, which minimizes the internal resistance and facilitates rapid ion transport, the electrical power of V-Mn AR-PIMB can reach as high as $\sim 600 \mathrm{~W} \mathrm{~cm}^{-3}$ with the energy density of $\sim 27 \mathrm{mWh} \mathrm{cm}^{-3}$, much higher than microsupercapacitors based on onion-like carbon ${ }^{9}$. To our knowledge, the volumetric energy and power densities of V-Mn AR-PIMBs is the highest value among recently reported aqueous alkaline-metalion batteries on the basis of $\mathrm{Li}^{+20}, \mathrm{Na}^{+26}, \mathrm{~K}^{+56}$, and $\mathrm{Zn}^{2+59}$ to date (Fig. 4f).

To meet specific micropower needs for portable or wearable electronics, all-solid-state flexible V-Mn AR-PIMBs are further developed by using a gel electrolyte of polyvinyl alcohol (PVA)/KCl and shifting on polymethyl methacrylate (PMMA) substrates (Fig. 5a). Because of the outstanding mechanical flexibility (inset of Fig. 5b), the all-solid-state microbatteries achieve almost the same capacity when bended from $0^{\circ}$ to $90^{\circ}$ (Fig. 5b). Furthermore, they can be connected in series to increase the working voltage and in parallel to store more energy, showing potential applications as stand-alone micropower sources or intermediate energy-storage components in electronic and optoelectronic microdevices. As demonstrated by a self-powered system that is constructed with $2-\mathrm{V}$ thin-film solar cells to harvest energy from renewable and sustainable sunlight (Supplementary Fig. 14a), two V-Mn AR-PIMBs in series are charged to store energy and then discharged to power LED light when sunlight is available and unavailable (Fig. 5c). Figure 5d displays their typical voltage-time profile during the processes of charge and discharge in a working voltage window of $0-3.2 \mathrm{~V}$. When solar cells are irradiated by sunlight, the voltage of the two-series V-Mn ARPIMBs increases to $3.2 \mathrm{~V}$ in $136 \mathrm{~s}$, meaning that the microbatteries can be charged successfully. While sunlight is unavailable, the $\mathrm{V}-\mathrm{Mn}$ AR-PIMBs are discharged for $100 \mathrm{~s}$ at $2.64 \mathrm{~A} \mathrm{~cm}^{-3}$, powering the LED light (Supplementary Fig. 14b).

\section{Discussion}

In summary, we have demonstrated representative layered TMOs, $\mathrm{K}_{x} \mathrm{~V}_{2} \mathrm{O}_{5}$, with an amorphous/crystalline dual-phase nanostructure, as promising anode materials of AR-PIMB when they are integrated on $3 \mathrm{D}$ bicontinuous nanoporous metal current microcollectors. Dual-phase nanostructuring of the layered $a c$ $\mathrm{K}_{x} \mathrm{~V}_{2} \mathrm{O}_{5}$ is to remove some crystal water and use the amorphous $\mathrm{K}_{0.25} \mathrm{~V}_{2} \mathrm{O}_{5} \cdot n \mathrm{H}_{2} \mathrm{O}$ as molecular pillars to support the large interlayer distance, which creates additional room in interlayer space 
to accommodate guest hydrated $\mathrm{K}^{+}$cations with significantly enhanced accessibility/diffusion kinetics. Associated with the unique architecture of 3D bicontinuous nanoporous metal-based current microcollectors, which simultaneously facilitate electron and ion transports in the whole microelectrodes, the NP Au/ac$\mathrm{K}_{x} \mathrm{~V}_{2} \mathrm{O}_{5}$ exhibits exceptionally energy storage with volumetric capacity of as high as $\sim 715 \mathrm{mAh} \mathrm{cm}^{-3}$, and high rate capability. The outstanding electrochemical properties enlist AR-PIMB, which are constructed by integrating the $a c-\mathrm{K}_{x} \mathrm{~V}_{2} \mathrm{O}_{5}$ anode and the $c-\mathrm{K}_{x} \mathrm{MnO}_{2}$ cathode on interdigitated $3 \mathrm{D}$ nanoporous $\mathrm{Au}$ current microcollectors, to really realize energy storage with lithium-ion microbattery-like capacity and supercapacitor-like rate performance and long-term cycling stability. Their maximum energy and power densities reach $\sim 103 \mathrm{mWh} \mathrm{cm}^{-3}$ and $\sim 600 \mathrm{~W}$ $\mathrm{cm}^{-3}$, outperforming not only commercially available energystorage devices, such as $4 \mathrm{~V} / 500 \mu \mathrm{Ah}$ Li thin-film battery and $2.75 \mathrm{~V} / 44 \mathrm{mF}$ activated carbon supercapacitors, but also previously reported aqueous alkaline ion batteries based on $\mathrm{Li}^{+}$, $\mathrm{Na}^{+}$, and $\mathrm{K}^{+}$, in addition to $\mathrm{Zn}^{2+}$. The superior performance makes them promising candidates as next-generation micropower sources for satisfying the demand of high-energy and -power densities in miniaturized portable electronics and MEMS.

\section{Methods}

Fabrication of aqueous potassium ion microbatteries. Microbattery devices were constructed by electrodepositing vanadium oxides and manganese oxides as anode and cathode, respectively, on interdigital-patterned Au current microcollectors with a 3D bicontinuous nanoporous architecture. Pure $\mathrm{Cr}(\sim 50-\mathrm{nm}$ thick), $\mathrm{Au}$ ( 100-nm-thick) and $\mathrm{Ag}_{75} \mathrm{Au}_{25}$ (at \%) alloy ( 750-nm-thick) films were consecutively sputtered on micropatterned molds consisting of 30 pairs of interdigital channels with the width of $50 \mu \mathrm{m}$ and the gap of $100 \mu \mathrm{m}$, which were firstly fabricated on glass substrates by a general lithography technology. After stripping the micropatterned mold in $5 \mathrm{wt} \% \mathrm{NaOH}$, the metallic patterns were annealed in Ar air at $500{ }^{\circ} \mathrm{C}$ for $2 \mathrm{~h}$ and then chemically dealloyed in concentrated $\mathrm{HNO}_{3}$ for $15 \mathrm{~min}$. Electrodeposition of electroactive TMOs on the as-prepared interdigital nanoporous $\mathrm{Au}$ patterns were carried out on a classic three-electrode setup (Iviumstat electrochemical analyser; Ivium Technology), in which Pt foil and Ag/ $\mathrm{AgCl}$ electrode were employed as the counter electrode and the reference electrode, respectively. For the anodes, potassium vanadium oxide $\left(\mathrm{K}_{x} \mathrm{~V}_{2} \mathrm{O}_{5} \cdot n \mathrm{H}_{2} \mathrm{O}\right)$ was electrodeposited by a potentiodynamic method in a $\mathrm{pH}=1.8$ electrolyte containing $100 \mathrm{mM} \mathrm{VOSO}_{4}, 30 \mathrm{~mL}$ pure water and $70 \mathrm{~mL}$ ethanol, as well as $\mathrm{K}_{2} \mathrm{SO}_{4}$ with various concentrations from 0 to $30 \mathrm{mM}$, followed by annealing at 25,200 , and $300{ }^{\circ} \mathrm{C}$ under ambient conditions for $12 \mathrm{~h}$. Based on the total transfer charge in the electrodepositing process, the loading density of $\mathrm{K}_{x} \mathrm{~V}_{2} \mathrm{O}_{5} \cdot n \mathrm{H}_{2} \mathrm{O}$ is calculated to be $1.88 \mathrm{~g} \mathrm{~cm}^{-3}$. While for the cathode, the cryptomelane $\mathrm{K}_{x} \mathrm{MnO}_{2} \cdot n \mathrm{H}_{2} \mathrm{O}$ was incorporated into the nanoporous $\mathrm{Au}$ microelectrodes by a pulse electrodeposition technology in $0.1 \mathrm{M} \mathrm{KMnO}_{4}$ neutral electrolyte. The loading mass of these TMOs was controlled by the transferred charges during the electrodeposition processes based on an assumption of $100 \%$ efficiency.

To develop all-solid-state flexible potassium ion microbatteries, PMMA film was deposited on the as-prepared nanoporous Au current microcollectors by dispersing $2 \mathrm{~mL}$ PMMA solution ( $4 \mathrm{wt} \%$ in ethyl lactate) and then baking on a hotplate at $80^{\circ} \mathrm{C}$ for $30 \mathrm{~min}$. After etching the $\mathrm{Cr}$ layer in $0.5 \mathrm{M}\left(\mathrm{NH}_{4}\right)_{2} \mathrm{Ce}\left(\mathrm{NO}_{3}\right)_{6}$ solution, the PMMA supported nanoporous gold micropatterns was exfoliated and incorporated with the $a c-\mathrm{K}_{x} \mathrm{~V}_{2} \mathrm{O}_{5}$ anode and the $c-\mathrm{K}_{x} \mathrm{MnO}_{2}$ cathode by the same procedures as that in the fabrication of rechargeable aqueous potassium ion microbatteries. Using PVA/KCl gel electrolyte, all-solid-state flexible potassium ion microbatteries are fabricated and sealed by PDMS for electrochemical test.

Microstructural and chemical characterizations. The microstructure and chemical composition of the anodic and cathodic electrodes in the microbatteries were characterized using a field-emission scanning electron microscope (JEOL JSM$6700 \mathrm{~F}, 15 \mathrm{keV}$ ) equipped with an X-ray energy-dispersive spectroscopy and a fieldemission transmission electron microscope (JEOL JEM-2100F, $200 \mathrm{keV}$ ). XRD measurements were carried out on a D/max2500pc diffractometer using $\mathrm{Cu} K_{\alpha}$ radiation. XPS was performed on an ESCAlab220i-XL electron spectrometer from VG Scientific using $\mathrm{Al} \mathrm{K}_{\alpha}$ radiation. TGA and DSC were measured on a DSC 7 analyzer at the ramping rate of $10^{\circ} \mathrm{C} \mathrm{min}-1$ in Ar air. Raman spectra were collected on a micro-Raman spectrometer (Renishaw) with a laser wavelength of $532 \mathrm{~nm}$ at $1 \mathrm{~mW}$.

Electrochemical measurements. Electrochemical properties of single anodic and cathodic electrodes were characterized in $0.5 \mathrm{M} \mathrm{K}_{2} \mathrm{SO}_{4}$ aqueous electrolyte on a classic three-electrode setup with $\mathrm{Pt}$ foil as the counter electrode and $\mathrm{Ag} / \mathrm{AgCl}$ as the reference electrode. Electrochemical behaviors of battery microdevices were measured by a two-electrode setup in $0.5 \mathrm{M} \mathrm{K}_{2} \mathrm{SO}_{4}$ aqueous electrolyte. Cycling stability test of potassium ion microbatteries was performed in a voltage window from 0 to $1.6 \mathrm{~V}$ at a scan rate of $500 \mathrm{mV} \mathrm{s}^{-1}$ for over 10000 cycles. Self-discharge measurements were carried out by charging aqueous potassium ion microbattery to $1.6 \mathrm{~V}$ at $110 \mu \mathrm{A}$, followed by open-circuit potential self-discharging for $100 \mathrm{~h}$

\section{Data availability}

All relevant data are available from the corresponding authors upon request.

Received: 18 December 2018 Accepted: 2 September 2019

Published online: 20 September 2019

\section{References}

1. Wang, Z. L. Self-power nanosensors and nanosystems. Adv. Mater. 24, 280-285 (2012).

2. Sun, H., Zhang, Y., Zhang, J., Sun, X. M. \& Peng, H. S. Energy harvesting and storage in 1D devices. Nat. Rev. Mater. 2, 17023 (2017).

3. Oudenhoven, J. F. M., Baggetto, L. \& Notten, P. H. L. All-solid-state lithiumion microbatteries: a review of various three-dimensional concepts. $A d v$. Energy Mater. 1, 10-33 (2011).

4. Pikul, J. H., Zhang, H. G., Cho, J., Braun, P. V. \& King, W. P. High-power lithium ion microbatteries from interdigitated three-dimensional bicontinuous nanoporous electrodes. Nat. Commun. 4, 1732 (2013).

5. Sun, K. et al. 3D printing of interdigitated Li-ion microbattery architectures. Adv. Mater. 25, 4539-4543 (2013)

6. Ning, H. et al. Holographic patterning of high-performance on-chip 3D lithium-ion microbatteries. Proc. Natl. Acad. Sci. USA 112, 6573-6578 (2015).

7. Hur, J. I., Smith, L. C. \& Dunn, B. High areal energy density 3 D lithium-ion microbatteries. Joule 2, 1187-1201 (2018).

8. Chmiola, J., Largeot, C., Taberna, P. L., Simon, P. \& Gogotsi, Y. Monolithic carbide-derived carbon films for micro-supercapacitors. Science 328, 480-483 (2010).

9. Pech, D. et al. Ultrahigh-power micrometer-sized supercapacitors based on onion-like carbon. Nat. Nanotechnol. 5, 651-654 (2010).

10. Gao, W. et al. Direct laser writing of micro-supercapacitors based hydrated graphite oxide films. Nat. Nanotechnol. 6, 496-500 (2011).

11. Kyeremateng, N. A., Brousse, T. \& Pech, D. Microsupercapacitors as miniaturized energy-storage components for on-chip electronics. Nat. Nanotechnol. 12, 7-15 (2017).

12. Peng, Y. Y. et al. All-MXene (2D titanium carbide) solid-state microsupercapacitors for on-chip energy storage. Energy Environ. Sci. 9, 2847-2854 (2016).

13. Lang, X. Y., Hirata, A., Fujita, T. \& Chen, M. W. Nanoporous metal/oxide hybrid electrodes for electrochemical supercapacitors. Nat. Nanotechnol. 6, 232-236 (2011).

14. Yu., D. S. et al. Scalable synthesis of hierarchically structured carbon nanotube-graphene fibers for capacitive energy storage. Nat. Nanotechnol. 9, 555-562 (2014).

15. Huang, P. et al. On-chip and freestanding elastic carbon films for microsupercapacitors. Science 351, 691-695 (2016).

16. Xia, Y. et al. Thickness-independent capacitance of vertically aligned liquidcrystalline MXenes. Nature 557, 409-412 (2018).

17. Liu, Y., Zhao, H. P. \& Lei, Y. Advances on three-dimensional electrodes for microsupercapacitors: a mini-review. InfoMat 1, 74-84 (2019).

18. Li, W., Dahn, J. R. \& Wainwright, D. S. Rechargeable lithium batteries with aqueous electrolytes. Science 264, 1115-1118 (1994).

19. Kim, H. et al. Aqueous rechargeable $\mathrm{Li}$ and $\mathrm{Na}$ ion batteries. Chem. Rev. 114, 11788-11827 (2014).

20. Dong, X., Chen, L., Su, X., Wang, Y. \& Xia, Y. Flexible aqueous lithium-ion battery with high safety and large volumetric energy density. Angew. Chem. Int. Ed. 55, 7474-7477 (2016).

21. Shan, X. Q. et al. Biphase cobalt-manganese oxide with high capacity and rate performance for aqueous sodium-ion electrochemical energy storage. Adv. Funct. Mater. 28, 1703266 (2018).

22. Guo, Z. W. et al. Multi-functional flexible aqueous sodium-ion batteries with high safety. Chem 3, 348-362 (2017).

23. Xie., F., Zhang, L., Su, D., Jaroniec, M. \& Qiao, S. Z. $\mathrm{Na}_{2} \mathrm{Ti}_{3} \mathrm{O}_{7} @ \mathrm{~N}$-doped carbon hollow spheres for sodium-ion batteries with excellent rate performance. Adv. Mater. 29, 1700989 (2017).

24. Zhang, B. W. et al. Long-life room-temperature sodium-sulfur batteries by virtue of transition-metal-nanocluster-sulfur interactions. Angew. Chem. Int. Ed. 58, 1484-1488 (2019). 
25. Charles, D. S. et al. Structural water engaged disordered vanadium oxide nanosheets for high capacity aqueous potassium-ion storage. Nat. Commun. 8 , 15520 (2017)

26. Wessells, C. D., Peddada, S. V., McDowell, M. T., Huggins, R. A. \& Cui, Y. The effect of insertion species on nanostructured open framework hexacyanoferrate battery electrodes. J. Electrochem. Soc. 159, A98-A103 (2012).

27. Su, D., McDonagh, A., Qiao, S. Z. \& Wang, G. High-capacity aqueous potassium-ion batteries for large-scale energy storage. Adv. Mater. 29, 1604007 (2017).

28. Zeng, C. et al. Ultrathin titanate nanosheets/graphene films derived from confined transformation for excellent $\mathrm{Na} / \mathrm{K}$ ion storage. Angew. Chem. Int. Ed. 57, 8540-8544 (2018).

29. Wang, F. et al. High-voltage aqueous magnesium ion batteries. ACS Cent. Sci. 3, 1121-1128 (2017)

30. Pan, H. et al. Reversible aqueous zinc/manganese oxide energy storage from conversion reactions. Nat. Energy 1, 16039 (2016).

31. Kundu, D., Adams, B. D., Duffort, V., Vajargah, S. H. \& Nazar, L. F. A highcapacity and long-life aqueous rechargeable zinc battery using a metal oxide intercalation cathode. Nat. Energy 1, 16119 (2016).

32. Smith, D. W. Ionic hydration enthalpies. J. Chem. Edu. 54, 540-542 (1977).

33. Nightingale, E. R. Phenomenological theory of ion solvation: effective radii of hydrated ions. J. Phys. Chem. 63, 1381-1387 (1959).

34. Esfandiar, A. et al. Size effect in ion transport through Angstrom-scale slits. Science 358, 511-513 (2017)

35. Wessells, C. D., Peddada, S. V., Huggins, R. A. \& Cui, Y. Nickel hexacyanoferrate nanoparticles electrodes for aqueous sodium and potassium ion batteries. Nano Lett. 11, 5421-5425 (2011).

36. Ren, W., Chen, X. \& Zhao, C. Ultrafast aqueous potassium-ion batteries cathode for stable intermittent grid-scale energy storage. Adv. Energy Mater. 8, 1801413 (2018).

37. Petkov, V. et al. Structure of $\mathrm{V}_{2} \mathrm{O}_{5} n \mathrm{H}_{2} \mathrm{O}$ xerogel solved by the atomic pair distribution function technique. J. Am. Chem. Soc. 124, 10157-10162 (2002).

38. Augustyn, V. \& Gogotsi, Y. 2D materials with nanoconfined fluids for electrochemical energy storage. Joule 1, 443-452 (2017).

39. Clites, M. \& Pomerantseva, E. Bilayered vanadium oxides by chemical preintercalation of alkaline and alkali-earth ions as battery electrodes. Energy Storage Mater. 11, 30-37 (2018).

40. Wang, J., Curtis, C. J., Schulz, D. L. \& Zhang, J.-G. Influences of treatment temperature and water content on capacity and rechargeability of $\mathrm{V}_{2} \mathrm{O}_{5}$ xerogel films. J. Electrochem. Soc. 151, A1-A7 (2004).

41. Liu, Q. et al. Graphene-modified nanostructured vanadium pentoxide hybrids with extraordinary electrochemical performance for Li-ion batteries. Nat. Commun. 6, 6127 (2015).

42. Coustier, F., Hill, J., Owens, B. B., Passerini, S. \& Smyrl, W. H. Doped vanadium oxides as host materials for lithium intercalation. J. Electrochem. Soc. 146, 1355-1360 (1999).

43. Levi, E., Gofer, Y. \& Aurbach, D. On the way to rechargeable Mg batteries: the challenge of new cathode materials. Chem. Mater. 22, 860-868 (2010).

44. Soga, N. \& Senna, M. Change in the dehydration and crystallization processes of $\mathrm{V}_{2} \mathrm{O}_{5}$ xerogel due to mechanical pretreatment. J. Solid State Chem. 107, 159-165 (1993).

45. He, P. et al. Sodium ion stabilized vanadium oxide nanowire cathode for highperformance zinc-ion batteries. Adv. Energy Mater. 8, 1702463 (2018).

46. Erlebacher, J., Aziz, M. J., Karma, A., Dimitrov, N. \& Sieradzki, K. Evolution of nanoporosity in dealloying. Nature 410, 450-453 (2001).

47. Yue, Y. \& Liang, H. Micro- and nano-structured vanadium pentoxide $\left(\mathrm{V}_{2} \mathrm{O}_{5}\right)$ for electrodes of lithium-ion batteries. Adv. Energy Mater. 7, 1602545 (2017).

48. Baddour-Hajean, R., Raekelboom, E. \& Pereira-Ramos, J. P. New structural characterization of the $\mathrm{Li}_{x} \mathrm{~V}_{2} \mathrm{O}_{5}$ system provided by Raman spectroscopy. Chem. Mater. 18, 3548-3556 (2006).

49. $\mathrm{Su}, \mathrm{D}$. \& Wang, G. Single-crystalline bilayered $\mathrm{V}_{2} \mathrm{O}_{5}$ nanobelts for highcapacity sodium-ion batteries. ACS Nano 7, 11218-11226 (2013).

50. Baddour-Hadjean, R., Boudaoud, A., Bach, S., Emery, N. \& Pereira-Ramos, J. P. A comparative insight of potassium vanadates as positive electrode materials for Li batteries: Influence of the long-range and local structure. Inorg. Chem. 53, 1764-1772 (2014).

51. Sathiya, M., Prakash, A. S., Ramesha, K., Tarascon, J. M. \& Shukla, A. K. $\mathrm{V}_{2} \mathrm{O}_{5}$-anchored carbon nanotubes for enhanced electrochemical energy storage. J. Am. Chem. Soc. 133, 16291-16299 (2011).
52. Lindström, H. et al. $\mathrm{Li}^{+}$ion insertion in $\mathrm{TiO}_{2}$ (anatase). 2. Voltmmetry on nanoporous films. J. Phys. Chem. B 101, 7717-7722 (1997).

53. Augustyn, V. et al. High-rate electrochemical energy storage though $\mathrm{Li}^{+}$ intercalation pseudocapacitance. Nat. Mater. 12, 518-522 (2013).

54. Yuan, Y. et al. The influence of large cations on the electrochemical properties of tunnel-structured metal oxides. Nat. Commun. 7, 13374 (2016).

55. Yao, X., Zhao, Y., Castro, F. A. \& Ma, L. Rational design of preintercalated electrodes for rechargeable batteries. ACS Energy Lett. 4, 771-778 (2019).

56. Li, R. Z. et al. Carbon-stabilized high-capacity ferroferric oxide nanorod array for flexible solid-state alkaline battery-supercapacitor hybrid device with high environmental suitability. Adv. Funct. Mater. 25, 5384-5394 (2015).

57. Zuo, W. H. et al. Bismuth oxide: a versatile high-capacity electrode material for rechargeable aqueous metal-ion batteries. Energy Environ. Sci. 9, 2881-2891 (2016).

58. Mirmohseni, A. \& Solhjo, R. Preparation and characterization of aqueous polyaniline battery using a modified polyaniline electrode. Eur. Polym. J. 39, 219-223 (2003).

59. Huang, Y. et al. Wearable, conductive yarn-based $\mathrm{NiCo} / / \mathrm{Zn}$ textile battery with high energy density and rate capability. ACS Nano 11, 8953-8961 (2017).

\section{Acknowledgements}

This work was supported by National Natural Science Foundation of China (Nos. 51871107, 51631004), Top-notch Young Talent Program of China (W02070051), Chang Jiang Scholar Program of China (Q2016064), the Program for JLU Science and Technology Innovative Research Team (JLUSTIRT, 2017TD-09), the Fundamental Research Funds for the Central Universities, and the Program for Innovative Research Team (in Science and Technology) in University of Jilin Province.

\section{Author contributions}

X.-Y.L., Q.J. and Y.-Q.L. conceived and designed the experiments. Y.-Q.L., H.S., S.-B.W., Y.-T.Z., Z.W. and X.-Y.L. carried out the fabrication and analysis of materials and performed the electrochemical and microstructural characterizations. X.-Y.L., Q.J. and Y.-Q.L. wrote the paper, and all authors discussed the results and commented on the manuscript.

\section{Additional information}

Supplementary information accompanies this paper at https://doi.org/10.1038/s41467 019-12274-7.

Competing interests: The authors declare no competing interests.

Reprints and permission information is available online at http://npg.nature.com/ reprintsandpermissions/

Peer review information Nature Communications thanks Wei Luo, Shizhang Qiao, and the other, anonymous, reviewer(s) for their contribution to the peer review of this work. Peer reviewer reports are available.

Publisher's note Springer Nature remains neutral with regard to jurisdictional claims in published maps and institutional affiliations.

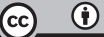

Open Access This article is licensed under a Creative Commons Attribution 4.0 International License, which permits use, sharing, adaptation, distribution and reproduction in any medium or format, as long as you give appropriate credit to the original author(s) and the source, provide a link to the Creative Commons license, and indicate if changes were made. The images or other third party material in this article are included in the article's Creative Commons license, unless indicated otherwise in a credit line to the material. If material is not included in the article's Creative Commons license and your intended use is not permitted by statutory regulation or exceeds the permitted use, you will need to obtain permission directly from the copyright holder. To view a copy of this license, visit http://creativecommons.org/ licenses/by/4.0/.

(C) The Author(s) 2019 